\title{
Investigation of Beta-Lactam and Tetracycline Group Antibiotic Residues in Bovine Liver, Kidney and Muscle Tissue
}

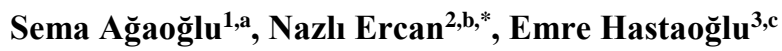 \\ ${ }^{1}$ Department of Food Hygiene and Technology, Faculty of Veterinary, Sivas Cumhuriyet University, 58140 Sivas, Turkey \\ ${ }^{2}$ Department of Biochemistry, Faculty of Veterinary, Sivas Cumhuriyet University, 58140 Sivas, Turkey \\ ${ }^{3}$ Department of Gastronomy and Culinary Arts, Faculty of Tourism, Sivas Cumhuriyet University, 58140 Sivas, Turkey \\ *Corresponding author
}

\begin{tabular}{|c|c|}
\hline A R T I C L E I N F O & A B S T R A C T \\
\hline $\begin{array}{l}\text { Received : 08/07/2021 } \\
\text { Accepted : 16/11/2021 }\end{array}$ & $\begin{array}{l}\text { In this study, beta-lactam and tetracycline antibiotic residues were investigated in cattle liver, } \\
\text { kidney and muscle samples. For this purpose, a total of } 75 \text { bovine tissue samples (each of } 25 \text { from } \\
\text { liver, kidney, muscle) taken from } 25 \text { cattle slaughtered in a local slaughterhouse in Sivas were used } \\
\text { as materials. ELISA method was applied in the analysis and it was studied with commercial test } \\
\text { kits. According to the results of the analysis; beta-lactam and tetracycline residues were detected in } \\
\text { all bovine tissue samples. Beta-lactam level was determined between } 0.75-1.07 \mathrm{ppb} \text { (mean } 0.94 \pm \\
0.01 \text { ) in liver samples, } 0.67-1.05 \mathrm{ppb} \text { (mean } 0.81 \pm 0.01) \text { in kidney samples and } 0.70-2.57 \mathrm{ppb} \text { (mean } \\
0.97 \pm 0.07 \text { ) in muscle samples. Tetracycline level was detected in the range of } 4.48-8.50 \mathrm{ppb} \text { (mean } \\
6.14 \pm 0.17 \text { ) in liver samples, } 1.73-6.39 \mathrm{ppb} \text { (mean } 4.90 \pm 0.24) \text { in kidney samples and } 3.31-7.45 \\
\text { ppb (mean } 5.67 \pm 0.25) \text { in muscle samples. The residue levels determined in the examples complied } \\
\text { with the legal limits reported in the European Commission and the Turkish Food Codex } \\
\text { Communiqué. }\end{array}$ \\
\hline
\end{tabular}

Tetracycline

Residue

ELISA

In this study, beta-lactam and tetracycline antibiotic residues were investigated in cattle liver, kidney and muscle samples. For this purpose, a total of 75 bovine tissue samples (each of 25 from as materials. ELISA method was applied in the analysis and it was studied with commercial test kits. According to the results of the analysis; beta-lactam and tetracycline residues were detected in all bovine tissue samples. Beta-lactam level was determined between 0.75-1.07 ppb (mean 0.94 $6.14 \pm 0.17$ ) in liver samples, $1.73-6.39 \mathrm{ppb}$ (mean $4.90 \pm 0.24$ ) in kidney samples and 3.31-7.45 with the legal limits reported in the European Commission and the Turkish Food Codex

\section{Introduction}

Protein deficiency is a nutritional problem that affects every age group in the world and in our country. The World Health Organization (WHO) has determined the daily protein requirement of a healthy individual to be $0.8-1 \mathrm{~g} /$ $\mathrm{kg}$ (body weight). This amount varies according to age, gender, health, physiological status and daily activity. Which is important for a healthy diet that $40-50 \%$ of the protein taken daily is of animal origin (Tayar and Yarsan, 2014).

Meat and meat products are an important food group in terms of animal proteins. Meat is food which rich in proteins, minerals (iron, zinc, phosphorus, sodium, potassium, magnesium) and vitamins (B1, B2, B6, B12) with high biological value. Essential amino acids that cannot be synthesized in the body, which must be taken with nutrients, are found in sufficient quantities and proportions in the composition of meat (Tayar and Yildirim, 2020).
Varieties of antibiotics are widely used in farm animals to treat and prevent diseases or accelerate growth. However, uncontrolled use of these drugs poses a risk to both consumer and animal health. After the last application, the "legal waiting period" of the animals applied to antibiotics is sent to slaughter before the completion, edible tissues and organs and animal food obtained from them causes the formation of residues. The same situation applies to dairy animals treated with antibiotics and other animals whose meat is suitable for human consumption (such as poultry, fish) (Tayar and Yarsan, 2014; Kaya, 2018).

Antibiotic residues in foods can causes such as susceptible individuals, drug allergy (allergic reactions, hypersensitivity, anaphylactic shock), antibiotic-resistant bacteria, the development of a disruption of the intestinal flora, sex characteristics a change in suppression of the immune system on endotoxic shock (septic shock), blood clotting, spoilage, food poisoning, some organs (liver, 
kidneys, organs of hearing and balance) irreversible damage, permanent staining of the teeth; carcinogenic, mutagenic and teratogenic effects; in the food industry, especially fermented products (fermented sausage, bacon, yogurt, cheese, butter), such as bacteria and preventing the development of starter cultures in the production of fermentation that enables manufacturing defects, environmental pollution and economic losses (Shea, 2003; Nisha, 2008; Landers et al., 2012; Darwish et al., 2013; Mensah et al., 2014; Beyene, 2016; Jayalakshmi et al., 2017; Tadesse and Tadesse, 2017; TÜBA, 2017; Kaya, 2018; Tesfaye, 2019).

The aim of this study was to determine the presence and level of beta-lactam and tetracycline group antibiotics in bovine liver, kidney and muscle tissue and to evaluate the findings in terms of public health.

\section{Material and Method}

\section{Material}

In this study, 75 bovine tissue samples (each of 25 from liver, kidney, muscle) were used as materials. Tissue samples were taken periodically from animals slaughtered in the slaughterhouse in September-October 2018, and were brought to the laboratory in a cold chain with sterile stomacher bags and analyzed on the same day. Samples were kept in the refrigerator $\left(+4^{\circ} \mathrm{C}\right)$ during this process.

\section{Method}

Beta-lactam and tetracycline levels were determined by ELISA (enzyme Linked Immunosorbent Assay) in bovine liver, kidney and muscle samples. Commercial test kits as Randox Food Diagnostic (REF BL3448) for beta-lactam and Sinogeneclon (REF SG4021) for tetracycline were used in the analyses.

Arithmetic mean, percentage, standard error, minimum, maximum values of beta-lactam and tetracycline detected in the samples were analyzed in the SPSS 22.00 package program (SPSS).

\section{Results}

Beta-lactam and tetracycline levels and \% distributions determined in bovine liver, kidney muscle samples are given in Table 1 and Table 2.

Table 1. Beta-lactam levels (ppb) and \% distribution in bovine liver, kidney and muscle samples

\begin{tabular}{|c|c|c|c|c|}
\hline & & $0.46-0.92$ & $0.92-4.60$ & Total \\
\hline Liver & \multirow{3}{*}{$\mathrm{n}$} & 10 & 15 & 25 \\
\hline Kidney & & 21 & 4 & 25 \\
\hline Muscle & & 13 & 12 & 25 \\
\hline Liver & \multirow{3}{*}{$\%$} & $40 \%$ & $60 \%$ & $100.0 \%$ \\
\hline Kidney & & $84 \%$ & $16 \%$ & $100.0 \%$ \\
\hline Muscle & & $52 \%$ & $48 \%$ & $100.0 \%$ \\
\hline Liver & \multirow{3}{*}{ Min. } & 0.75 & 0.93 & 0.75 \\
\hline Kidney & & 0.67 & 0.94 & 0.67 \\
\hline Muscle & & 0.70 & 0.93 & 0.70 \\
\hline Liver & \multirow{3}{*}{ Max. } & 0.92 & 1.07 & 1.07 \\
\hline Kidney & & 0.89 & 1.05 & 1.05 \\
\hline Muscle & & 0.92 & 2.57 & 2.57 \\
\hline Liver & \multirow{3}{*}{ Mean \pm SE } & $0.85 \pm 0.01$ & $0.99 \pm 0.01$ & $0.94 \pm 0.01$ \\
\hline Kidney & & $0.78 \pm 0.01$ & $0.97 \pm 0.02$ & $0.81 \pm 0.01$ \\
\hline Muscle & & $0.82 \pm 0.02$ & $1.12 \pm 0.13$ & $0.97 \pm 0.07$ \\
\hline
\end{tabular}

Table 2. Tetracycline levels (ppb) and \% distribution in bovine liver, kidney and muscle samples

\begin{tabular}{lc|ccc}
\hline \multicolumn{2}{c}{ Tetracycline $(\mathrm{ppb})$} & $1.35-4.05$ & $>4.05$ & Total \\
\hline Liver & & - & 25 & 25 \\
Kidney & $\mathrm{n}$ & 7 & 18 & 25 \\
Muscle & & 3 & 22 & 25 \\
\hline Liver & & - & $100.0 \%$ & $100.0 \%$ \\
Kidney & $\%$ & $28 \%$ & $72 \%$ & $100.0 \%$ \\
Muscle & & $12 \%$ & $88 \%$ & $100.0 \%$ \\
\hline Liver & & - & 4.48 & 4.48 \\
Kidney & \multirow{2}{*}{ Min. } & 1.73 & 4.19 & 1.73 \\
Muscle & & 3.31 & 4.13 & 3.31 \\
\hline Liver & & - & 8.50 & 8.50 \\
Kidney & \multirow{2}{*}{ Max. } & 3.83 & 6.39 & 6.39 \\
Muscle & & 3.99 & 7.45 & 7.45 \\
\hline Liver & & - & $6.14 \pm 0.17$ & $6.14 \pm 0.17$ \\
Kidney & & $3.37 \pm 0.28$ & $5.49 \pm 0.17$ & $4.90 \pm 0.24$ \\
Muscle & \multirow{2}{*}{ Mean \pm SE } & $3.69 \pm 0.20$ & $5.94 \pm 0.23$ & $5.67 \pm 0.25$ \\
\hline
\end{tabular}


According to the results of the analysis, beta-lactam and tetracycline residues were detected in all of the bovine tissue samples (liver, kidney, muscle) which examined. Tetracycline levels were higher in all samples. Beta-lactam levels (mean) were determined as $0.94 \pm 0.01 \mathrm{ppb}$ in liver samples, $0.81 \pm 0.01 \mathrm{ppb}$ in kidney samples and $0.97 \pm 0.07$ ppb in muscle samples. Tetracycline levels (mean) were found to be $6.14 \pm 0.17 \mathrm{ppb}$ in liver samples, $4.90 \pm 0.24 \mathrm{ppb}$ in kidney samples and $5.67 \pm 0.25 \mathrm{ppb}$ in muscle samples.

\section{Discussion}

Antibiotics are widely used in farm animals to treat and prevent diseases or accelerate growth and development. However, in addition to their positive effects, their improper use without the knowledge of the veterinarian poses a potential danger to human and animal health. This is also leads to economic losses.

In this study, the presence and level of beta-lactam and tetracycline group of antibiotics were investigated in cattle liver, kidney and muscle samples in Sivas province.

According to the results of the analysis, beta-lactam and tetracycline group antibiotic residues were detected in all of the bovine tissue samples which examined. Beta-lactam levels were determined between $0.75-1.07 \mathrm{ppb}$ in liver samples (mean 0.94 \pm 0.01 ), 0.67-1.05 ppb in kidney samples (mean 0.81 \pm 0.01 ) and $0.70-2.57 \mathrm{ppb}$ in muscle samples (mean $0.97 \pm 0.07$ ). Tetracycline values were found between 4.48-8.50 ppb in liver samples (mean 6.14 \pm 0.17 ppb), 1.73-6.39 ppb in kidney samples (mean $4.90 \pm 0.24$ $\mathrm{ppb}$ ), in muscle samples 3.31-7.45 ppb (mean 5.67 \pm 0.25 ppb) (Table 1-2).

The levels of antibiotics and residues detected in various tissue samples in studies conducted in Turkey and other countries are given in Table 3 and Table 4.

Kaya et al. (1992), were found antibiotic residue in $21 \%$ of liver and kidney samples and $9 \%$ of muscle samples in an analysis of 255 bovine tissues (muscle, liver, kidney). Yuksek (2001) was found oxytetracycline residue in 7 kidney samples in an analysis of 50 bovine tissues (muscle, liver, kidney, spleen). Koc (2006) reported that quinolone residue was not found in any of the samples in an analysis of 240 samples of beef and mutton. Oruc et al. (2007), in an analysis of 60 beef samples, in 4 samples (6\%) streptomycin (mean $38.7 \mu \mathrm{g} / \mathrm{kg}$ ), 1 sample (1.5\%) of sulfamethazine (mean $12 \mu \mathrm{g} / \mathrm{kg}$ ). Erdogdu et al. (2009), were found tetracycline residue in 13 samples in an analysis of 275 samples of beef and mutton. Residue level was determined between $275-2540 \mu \mathrm{g} / \mathrm{kg}$. Er et al. (2013), identified quinolone residue in 60 samples $(57.7 \%)$ in an analysis of 104 beef samples. Residue level was determined as $6.64 \mu \mathrm{g} / \mathrm{kg}$ (Table 3).

In this study, the mean tetracycline level determined in bovine muscle samples were found lower than the reported value by Erdogdu et al. (2009). There weren't any research papers about beta-lactam residue in bovine tissue in a literature review.

They determined in studies conducted in other countries were examined; Muriuki et al. (2001) determined tetracycline level between $524-1.046 \mu \mathrm{g} / \mathrm{kg}$ in bovine tissue (muscle, liver, kidney); Abbasi et al. (2012) found $226.3 \mathrm{ng} / \mathrm{g}$ in bovine muscle, $651.3 \mathrm{ng} / \mathrm{g}$ in liver and 672.4 $\mathrm{ng} / \mathrm{g}$ in kidney samples. The level of tetracycline in the tissue samples they examined as; Abbasi et al. (2009) 33.8 $\mu \mathrm{g} / \mathrm{kg}$ (bovine muscle); Vragovic et al. (2011) $1.62 \mu \mathrm{g} / \mathrm{kg}$ (beef); Abdullah et al. (2012) 26.04-282.21 $\mu \mathrm{g} / \mathrm{kg}$ (beef) and 26.12-102.89 $\mu \mathrm{g} / \mathrm{kg}$ (mutton); Ramatla et al. (2017) $48.6 \mu \mathrm{g} / \mathrm{kg}$ (bovine muscle), $92.3 \mu \mathrm{g} / \mathrm{kg}$ (bovine liver), and $192.2 \mu \mathrm{g} / \mathrm{kg}$ (bovine kidney); Baghani et al. (2019) 0.2 ng/g (beef); Biswas et al. (2007), $0.08 \mu \mathrm{g} / \mathrm{g}$ (beef); Olatoye and Ehinmowo (2010), $51.8 \mu \mathrm{g} / \mathrm{kg}, 372.7 \mu \mathrm{g} / \mathrm{kg}$ and $1197.7 \mu \mathrm{g} / \mathrm{kg}$, respectively, in muscle, kidney and liver samples; Al-Gendy et al. (2014), $109.5 \mu \mathrm{g} / \mathrm{kg}$ in meat samples, 584.7 in liver samples and $1115.2 \mu \mathrm{g} / \mathrm{kg}$ in kidney samples; ampicillin levels in the same order as 17.5, 50 and $72.3 \mu \mathrm{g} / \mathrm{kg}$; Emiri et al. (2014), 57-100 $\mu \mathrm{g} / \mathrm{kg}$ (beef) (Table 4).

Table 3. Antibiotic residues in animal tissue samples in studies conducted in Turkey.

\begin{tabular}{|c|c|c|c|c|c|c|}
\hline City & $\mathrm{n}$ & Tissue & Antibiotic & $\mathrm{n}_{1}(\%)$ & Residue level & Reference \\
\hline Ankara & 255 & $\begin{array}{l}\text { Beef tissue } \\
\text { Muscle } \\
\text { Liver } \\
\text { Kidney }\end{array}$ & Different type & $\begin{array}{l}(9 \%) \\
(21 \%) \\
(21 \%)\end{array}$ & & Kaya et al. (1992) \\
\hline Ankara & 50 & $\begin{array}{l}\text { Beef tissue } \\
\text { Muscle } \\
\text { Liver } \\
\text { Kidney } \\
\text { Spleen }\end{array}$ & Oxytetracycline & 7 (kidney) & & Yuksek (2001) \\
\hline Ankara & 240 & $\begin{array}{l}\text { Beef } \\
\text { Mutton }\end{array}$ & Quinolone & & & Koc (2006) \\
\hline Bursa & 60 & Beef & $\begin{array}{l}\text { Streptomycin } \\
\text { Sulfamethazine }\end{array}$ & $\begin{array}{c}4(6 \%) \\
1(1.5 \%)\end{array}$ & $\begin{array}{c}38.27 \mu \mathrm{g} / \mathrm{kg} \\
12 \mu \mathrm{g} / \mathrm{kg}\end{array}$ & Oruc et al. (2007) \\
\hline $\begin{array}{l}\text { Different } \\
\text { cities }\end{array}$ & 275 & $\begin{array}{l}\text { Beef } \\
\text { Mutton }\end{array}$ & Tetracycline & 13 & $275-2540 \mu \mathrm{g} / \mathrm{kg}$ & $\begin{array}{l}\text { Erdogdu et al. } \\
\text { (2009) }\end{array}$ \\
\hline Ankara & $\begin{array}{l}104 \\
127\end{array}$ & $\begin{array}{l}\text { Beef } \\
\text { Chicken }\end{array}$ & Quinolone & $\begin{array}{l}60(57.7 \%) \\
58(45.7 \%)\end{array}$ & $\begin{array}{c}6.64 \mu \mathrm{g} / \mathrm{kg} \\
30.81 \mu \mathrm{g} / \mathrm{kg}\end{array}$ & Er et al. (2013) \\
\hline
\end{tabular}


Table 4. Antibiotic residues in animal tissue samples in studies conducted in various countries

\begin{tabular}{|c|c|c|c|c|c|c|}
\hline Country & $\mathrm{n}$ & Tissue & Antibiotic & $\mathrm{n}_{1}(\%)$ & Residue level & Reference \\
\hline Kenya & 250 & $\begin{array}{l}\text { Bovine tissue } \\
\text { Muscle } \\
\text { Liver } \\
\text { Kidney }\end{array}$ & $\begin{array}{c}\text { Tetracycline } \\
\text { Oxytetracycline } \\
\text { Chlortetracycline }\end{array}$ & $\begin{array}{c}114 \\
(45.6 \%) \\
110(44 \%) \\
4(1.6 \%) \\
\end{array}$ & $524-1.046 \mu \mathrm{g} / \mathrm{kg}$ & Muriuki et al. (2001) \\
\hline India & 122 & Beef & Oxytetracycline & 5 & $0.08 \mu \mathrm{g} / \mathrm{g}$ & Biswas et al. (2007) \\
\hline Iran & 500 & $\begin{array}{l}\text { Bovine tissue } \\
\text { Muscle } \\
\text { Liver } \\
\text { Kidney }\end{array}$ & $\begin{array}{c}\text { Tetracycline } \\
\text { Oxytetracycline } \\
\text { Chlortetracycline }\end{array}$ & $380(74 \%)$ & $\begin{array}{c}33.8 \mu \mathrm{g} / \mathrm{kg} \\
52.2 \mu \mathrm{g} / \mathrm{kg} \\
125.2 \mu \mathrm{g} / \mathrm{kg}\end{array}$ & Abbasi et al. (2009) \\
\hline Nigeria & 180 & $\begin{array}{l}\text { Bovine tissue } \\
\text { Muscle } \\
\text { Liver } \\
\text { Kidney }\end{array}$ & Oxytetracycline & $\begin{array}{l}17 \\
48 \\
33 \\
\end{array}$ & $\begin{array}{c}51.8 \mu \mathrm{g} / \mathrm{kg} \\
372.7 \mu \mathrm{g} / \mathrm{kg} \\
1197.7 \mu \mathrm{g} / \mathrm{kg}\end{array}$ & $\begin{array}{c}\text { Olatoye and } \\
\text { Ehinmowo (2010) }\end{array}$ \\
\hline Croatia & 75 & Beef & $\begin{array}{l}\text { Streptomycin } \\
\text { Tetracycline }\end{array}$ & $\begin{array}{l}(91 \%) \\
(96 \%)\end{array}$ & $\begin{array}{c}44.14 \mu \mathrm{g} / \mathrm{kg} \\
1.62 \mu \mathrm{g} / \mathrm{kg}\end{array}$ & $\begin{array}{l}\text { Vragovic et al. } \\
\text { (2011) }\end{array}$ \\
\hline İran & 100 & $\begin{array}{l}\text { Bovine tissue } \\
\text { Muscle } \\
\text { Liver } \\
\text { Kidney }\end{array}$ & Tetracycline & $\begin{array}{l}66 \\
12 \\
22\end{array}$ & $\begin{array}{l}226.3 \mathrm{ng} / \mathrm{g} \\
651.3 \mathrm{ng} / \mathrm{g} \\
672.4 \mathrm{ng} / \mathrm{g}\end{array}$ & Abbasi et al. (2012) \\
\hline Iraq & $\begin{array}{l}23 \\
22\end{array}$ & $\begin{array}{l}\text { Beef } \\
\text { Mutton }\end{array}$ & Tetracycline & $\begin{array}{c}14 \\
(60.86 \%) \\
11(50 \%)\end{array}$ & $\begin{array}{c}26.04-282.21 \\
\mu \mathrm{g} / \mathrm{kg} \\
26.12-102.89 \\
\mu \mathrm{g} / \mathrm{kg}\end{array}$ & $\begin{array}{l}\text { Abdullah et al. } \\
\qquad(2012)\end{array}$ \\
\hline Egypt & 90 & $\begin{array}{l}\text { Sheep tissue } \\
\text { Muscle } \\
\text { Liver } \\
\text { Kidney }\end{array}$ & Oxytetracycline & $\begin{array}{c}(13.33 \%) \\
(20 \%) \\
(33.33 \%) \\
\end{array}$ & $\begin{array}{c}109.5 \mu \mathrm{g} / \mathrm{kg} \\
584.7 \mu \mathrm{g} / \mathrm{kg} \\
1115.2 \mu \mathrm{g} / \mathrm{kg}\end{array}$ & $\begin{array}{l}\text { Al-Gendy et al. } \\
\text { (2014) }\end{array}$ \\
\hline Albania & 37 & Beef & Oxytetracycline & 4 & $57-100 \mu \mathrm{g} / \mathrm{kg}$ & Emiri et al. (2014) \\
\hline Tanzania & 60 & $\begin{array}{l}\text { Bovine tissue } \\
\text { Muscle } \\
\text { Liver } \\
\text { Kidney }\end{array}$ & Oxytetracycline & $60(71.1 \%)$ & $\begin{array}{l}2604.1 \mu \mathrm{g} / \mathrm{kg} \\
3434.4 \mu \mathrm{g} / \mathrm{kg} \\
3533.1 \mu \mathrm{g} / \mathrm{kg}\end{array}$ & Kimera et al. (2015) \\
\hline Tanzania & 171 & $\begin{array}{l}\text { Bovine tissue } \\
\text { Muscle } \\
\text { Liver } \\
\text { Kidney }\end{array}$ & Oxytetracycline & $87(51 \%)$ & $\begin{array}{c}0-11.72 \mathrm{mg} / \mathrm{kg} \\
0.19-3.0 \mathrm{mg} / \mathrm{kg} \\
0.01-1.67 \mathrm{mg} / \mathrm{kg}\end{array}$ & Bilashoboka (2016) \\
\hline Egypt & 30 & Beef & $\begin{array}{l}\text { Oxytetracycline } \\
\text { Penicillin }\end{array}$ & $\begin{array}{c}11 \\
(36.67 \%) \\
7(23.33 \%) \\
\end{array}$ & $\begin{array}{c}17.5-601.8 \mu \mathrm{g} / \mathrm{kg} \\
5.9-71.3 \mu \mathrm{g} / \mathrm{kg}\end{array}$ & $\begin{array}{l}\text { Elbagory et al. } \\
\qquad(2017)\end{array}$ \\
\hline Tanzania & 60 & Beef & Oxytetracycline & $21(35 \%)$ & $0.69 \mathrm{ng} / \mathrm{g}$ & Mgonja et al. (2017) \\
\hline Cameroon & 404 & $\begin{array}{l}\text { Bovine tissue } \\
\text { Muscle } \\
\text { Liver }\end{array}$ & $\begin{array}{c}\text { Penicillin G } \\
\text { Oxytetracycline }\end{array}$ & & $\begin{array}{c}17.58 \mu \mathrm{g} / \mathrm{kg} \\
240 \mu \mathrm{g} / \mathrm{kg}\end{array}$ & Vougat et al. (2017) \\
\hline $\begin{array}{l}\text { South } \\
\text { Africa }\end{array}$ & 50 & $\begin{array}{l}\text { Bovine tissue } \\
\text { Muscle } \\
\text { Liver } \\
\text { Kidney }\end{array}$ & Tetracycline & $\begin{array}{c}3(20 \%) \\
5(29.4 \%) \\
5(27.7 \%) \\
\end{array}$ & $\begin{array}{c}48.6 \mu \mathrm{g} / \mathrm{kg} \\
92.3 \mu \mathrm{g} / \mathrm{kg} \\
192.2 \mu \mathrm{g} / \mathrm{kg}\end{array}$ & Ramatla et al. (2017) \\
\hline Zambia & 224 & Beef & $\begin{array}{l}\text { Oxytetracyline } \\
\text { Sulfamethazine }\end{array}$ & $\begin{array}{l}77(34.4 \%) \\
39(17.4 \%)\end{array}$ & $\begin{array}{l}196.6 \mathrm{ng} / \mathrm{g} \\
86.5 \mathrm{ng} / \mathrm{g}\end{array}$ & Nchima et al. (2017) \\
\hline Ethiopia & 250 & Beef & $\begin{array}{c}\text { Oxytetracyline } \\
\text { Beta-lactam } \\
\text { Sulfonamide } \\
\end{array}$ & $\begin{array}{c}191 \\
(76.4 \%) \\
\end{array}$ & $\begin{array}{c}100 \mu \mathrm{g} / \mathrm{kg} \\
5 \mu \mathrm{g} / \mathrm{kg} \\
100 \mu \mathrm{g} / \mathrm{kg} \\
\end{array}$ & $\begin{array}{c}\text { Agmas and Adugna } \\
\text { (2018) }\end{array}$ \\
\hline Tanzania & 171 & $\begin{array}{l}\text { Bovine tissue } \\
\text { Muscle } \\
\text { Liver } \\
\text { Kidney }\end{array}$ & Oxytetracyline & $\begin{array}{c}137 \\
20 \\
14\end{array}$ & $\begin{array}{c}6 \mathrm{mg} / \mathrm{kg} \\
0.25 \mathrm{mg} / \mathrm{kg} \\
1.28 \mathrm{mg} / \mathrm{kg}\end{array}$ & $\begin{array}{l}\text { Bilashoboka et al. } \\
\text { (2019) }\end{array}$ \\
\hline Iran & 41 & Beef & $\begin{array}{l}\text { Ciprofloxacin } \\
\text { Tetracycline }\end{array}$ & $\begin{array}{l}41(100 \%) \\
31(75 \%)\end{array}$ & $\begin{array}{l}0,8 \mathrm{ng} / \mathrm{g} \\
0.2 \mathrm{ng} / \mathrm{g}\end{array}$ & Baghani et al. (2019) \\
\hline
\end{tabular}


In the studies were determined oxytetracycline levels as Kimera et al. (2015), $2604.1 \mu \mathrm{g} / \mathrm{kg}$ in meat samples, 3434.4 in liver samples and $3533.1 \mu \mathrm{g} / \mathrm{kg}$ in kidney samples; Bilashoboka (2016), between 0-10.72 in meat samples (mean 0.60), in liver samples 0.19-3.0 (mean 1.28) and $0.01-1.67 \mathrm{mg} / \mathrm{kg}$ in kidney samples (mean 0.26); Elbagory et al. (2017), $17.5-601.8 \mu \mathrm{g} / \mathrm{kg}$ in beef; Mgonja et al. (2017), ort. $0.69 \mathrm{ng} / \mathrm{g}$; Vougat et al. (2017), $240 \mu \mathrm{g} / \mathrm{kg}$ (et); Nchima et al. (2017), $196.6 \mathrm{ng} / \mathrm{g}$ in beef; Agmas and Adugna (2018), $100 \mu \mathrm{g} / \mathrm{kg}$ in beef; Bilashoboka et al. (2019), $6.0 \mathrm{mg} / \mathrm{kg}$ in muscle samples, $0.25 \mathrm{mg} / \mathrm{kg}$ in liver samples and $28 \mathrm{mg} / \mathrm{kg}$ in kidney samples (Table 4).

In this study, the mean level of tetracycline determined in bovine muscles did not parallel the findings of these researchers. In the same way, tetracycline values detected in liver and kidney samples were found to be lower than by some researcher's results (Abbasi et al., 2012; Ramatla et al., 2017).

The differences between the research findings can be explained by the fact that the studies were conducted in different years, the number of samples and the methods applied were different. In addition, regional differences have probably been influential in this regard.

Tetracycline group antibiotics (chlortetracycline, oxytetracycline, tetracycline) the maximum residue limit (MRL) in bovine muscle, liver and kidney, respectively, in the 200,600 , and $1200 \mathrm{mg} / \mathrm{kg}$ as determined by the Codex Alimentarius Commission (CAC, 2018). MRL values for amoxicillin and benzyl penicillin (penicillin G) group of Beta-lactam antibiotics were determined as $50 \mu \mathrm{g} / \mathrm{kg}$ in muscle, liver and kidney (bovine). The tetracycline group determined the MRL value of antibiotics in muscle, liver and kidney as 100, 300 and $600 \mu \mathrm{g} / \mathrm{kg}$, respectively in all food-produced species by Commission of the European Union (EU) (EU, 2010). MRL values for amoxicillin and benzyl penicillin were determined as $50 \mu \mathrm{g} / \mathrm{kg}$ in muscle, liver and kidney (bovine).

MRL values related to veterinary drugs in animal foods are regulated in the "Turkish food Codex regulation on the classification and Maximum Residue Limits of pharmacological active substances that can be found in animal foods (TGK, 2017)", prepared in accordance with EU legislation in Turkey. MRL value for tetracycline (the sum of the main substance and 4 epimers) in all foodproduced/producing species was determined as $100 \mu \mathrm{g} / \mathrm{kg}$, $300 \mu \mathrm{g} / \mathrm{kg}$ and $600 \mu \mathrm{g} / \mathrm{kg}$ in muscle, liver and kidney respectively in the regulation. MRL values for amoxicillin and benzyl penicillin in all food-produced species have been reported as $50 \mu \mathrm{g} / \mathrm{kg}$ in muscle, liver and kidney.

In this study, tetracycline levels detected in bovine tissue samples (muscle, liver, kidney) conformed to the limit values reported in European standards and the Turkish Food Codex (EU, 2010; TGK, 2017; CAC, 2018).

\section{Conclusion}

When the research findings were examined, betalactam and tetracycline group antibiotic residues were detected in all the samples which analyzed. However, the values determined were found to be in accordance with the legal limits. At the same time, the presence of antibiotic residue in all samples indicates that these antibiotics are widely used. In solving the residue problem caused by antibiotics, public organizations, veterinarians, animal breeders, food manufacturers, pharmaceutical companies, units related to the distribution and sale of drugs have important responsibilities. In order to prevent or limit drug residues in animal foods, the veterinarian should be aware of the responsibility and equipped with information, the diagnosis of the disease, drug selection, dose of the drug, method of administration and duration of treatment should be done correctly. Animal owners or animal breeders should be trained in relation to the subject. Animals with food value should not be sent to slaughter until the legal waiting period is complete following the administration of antibiotics. The drugs used in veterinary or animal by animal breeders must record and the records should include the type, of animal, drug type, dose, dose interval, application type, and duration of use, side effects and the treatment result information. Veterinary drugs should not be used as a growth factor in animals with food value. This practice was banned in Turkey in 2006 in line with the EU. However, this restriction does not apply in some countries (USA, Canada, Brazil, China). Waste belonging to animals treated with antibiotics should not be used as feed additives. Pharmaceutical companies should be aware of responsibility and animal owners should be properly informed. Chip earrings should be used in animals and drug tracking system (DTS) should be used by applying square code for the traceability of veterinary drugs. Analysis methods and studies should be revised and improved as part of the residue monitoring and control program maintained by the Ministry of Agriculture and Forestry. Necessary legal actions should be taken by the authorized institutions or organizations if residues above the tolerance level are detected.

\section{Acknowledgements}

This work is supported by the Scientific Research Project Fund of Sivas Cumhuriyet University under the project number 'V-071'.

\section{References}

Abbasi MM, Rashidi MR, Javadi A, Bannazadeh M, Mirmahdavi S, Zabihi M. 2009. Levels of tetracycline residues in cattle meat, liver and kidney from a slaughter house in Tabriz, Iran. Turkish Journal of Veterinary and Animal Science, 33(4):345-349.

Abbasi MM, Nemati MH, Babaei H, Ansarin M, Nourdadgar A. 2012. Solid-Phase extraction and simultaneous determination of tetracycline residues in edible cattle tissues using and HPLC-FL method. Iranian Journal of Pharmaceutical Research, 11(3):781-787.

Abdullah OA, Shareef AM, Sheet OH. 2012. Detection of streptomycin residues in local meat of bovine and ovine. Iraqi Journal of Veterinary Science, 26(1):43-46.

Agmas B, Adugna M. 2018. Antimicrobial residue occurrence and its public health risk of beef meat in Debre Tabor and Bahir Dar, Northwest Ethiopia. Veterinary World, 11(7):902908.

Al-Gendy HM, Hasanen FS, Salem AM, Nada SM. 2014. Assessment of oxytetracycline and ampicillin residues in sheep carcasses. Benha Veterinary Medical Journal, 27(2):188-196. 
Baghani A, Mesdaghinia A, Rafieiyan M, Dallal MMS, Douraghi M. 2019. Tetracycline and ciprofloxacin multiresidues in beef and chicken meat samples using indirect competitive ELISA. Journal of Immunoassay and Immunochemistry, 40(3):328342.

Beyene T. 2016. Veterinary drug residues in food-animal products: Its risk factors and potential effects on public health. Journal of Veterinary Science and Technology, 7:1-7.

Bilashoboka E. 2016. Assessment of oxytetracycline residue levels in beef consumed in Dodoma municipality catchment area, Tanzania. Masters of Science in Epidemiology and Biostatistics. Department of Public Health, the University of Zambia.

Bilashoboka E, Mudenda B, Munyinda N, Moshi FV, Kambarage DM. 2019. Determination of oxytetracycline residue levels in edible tissues of slaughtered cattle. Food and Environment Safety Journal, 17(4).

Biswas AK, Rao GS, Kondaiah N, Anjaneyulu ASR, Mendiratta SK, Prasad R, Malik JK. 2007. Simple multi-residue method for determination of oxytetracycline, tetracycline and chlortetracycline in export buffalo meat by HPLC-photodiode array detector. Journal of Food and Drug Analysis, 15(3):278284.

Codex Alimentarius (CAC). 2018. Maximum Residue Limits (MRLs) and Risk Management Recommendations (RMRs) for Residues of Veterinary Drugs in Foods. International Food Standards, CX/MRL 2-2018.

Darwish WS, Eldaly EA, El-Abbasy MT, Ikenaka Y, Nakayama S, Ishizuka M. 2013. Antibiotic residues in food: The African scenario. Japanese Journal of Veterinary Research 61(Supplement), 513-522.

Elbagory AM, Edris AM, Muhammad KM. 2017. Studies and residues of antibiotics and growth enhancer-hormone in imported and locally produced beef. Nutrition and Food Technology: Open Access, 3(2).

Emiri A, Myftari E, Çoçoli S, Treska E. 2014. Determination of oxytetracycline, tetracycline and chlortetracycline in beef meat by HPLC-DAD detector in Albania. Albanian Journal of Agricultural Sciences (Special edition), 489-493.

Er B, Onurdağ FK, Demirhan B, Özgacar SÖ, Öktem AB, Abbasoğlu U. 2013. Screening of quinolone antibiotic residues in chicken meat and beef sold in the markets of Ankara, Turkey. Poultry Science, 92(8):2212-2215.

Erdoğdu AT, Koçyiğit Y, Özdemir G, Coşkun Y. 2009. Tüketime sunulan sığır ve koyun etlerinde tetrasiklin türevi antibiyotiklerin kalıntılarının belirlenmesi. 3. Ulusal Veteriner G1da Hijyeni Kongresi Kitab1, p. 175, Bursa.

European Commission. 2010. Commission Regulation (EU) No 37/2010 of 22 December 2009 on Pharmacologically Active Substances and Their Classification Regarding Maximum Residue Limits in Foodstuffs of Animal Origin. Official Journal of the European Union, 15:1-72.

Jayalakshmi K, Paramasivam M, Sasikala M, Tamilam TV, Sumithra A. 2017. Review on antibiotic residues in animal products and its impact on environments and human health. Journal of Entomology and Zoology Studies, 5(3):1446-1451.

Kaya S. 2018. Hayvansal gıdalarda ilaç kalıntıları ve tüketici sağlığı. International Journal of Scientific and Technological Research, 4(8): 28-37.

Kaya S, Yavuz H, Akar F, Liman BC, Filazi A. 1992. Mezbahadan sağlanan sığır et, karaciğer ve böbrek örneklerinde antibiyotik kalıntıları. Ankara Üniversitesi Veteriner Fakültesi Dergisi, 39(1-2):13-29.

Kimera ZI, Mdegela RH, Mhaiki CJN, Karimuribo ED, Mabiki F, Nonga HE, Mwesongo J. 2015. Determination of oxytetracycline residues in cattle meat marketed in the Kilosa district, Tanzania. Onderstepoort Journal of Veterinary Research, 82(1):911.
Koç F. 2006. Screening of quinolone residues in animal tissues. Indian Veterinary Journal, 83:1063-1064.

Landers TF, Cohen B, Wittum TE, Larson EL. 2012. A review of antibiotic use in food animals: perspective, policy, and potential. Public Health Reports, 127(1):4-22.

Mensah SEP, Koudande OD, Sanders P, Laurentie M, Mensah GA, Abiola FA. 2014. Antimicrobial residues in foods of animal origin in Africa: Public health risks. Scientific and technical review (International Office of Epizootics), 33(3):987-996, 975-986.

Mgonja F, Mosha R, Mabiki F, Choongo K. 2017. Oxytetracycline residue levels in beef in Dodoma region, Tanzania. African Journal of Food Science, 11(2), 40-43.

Muriuki FK, Ogara WO, Njeruh FM, Mitema ES. 2001. Tetracycline residue levels in cattle meat from Nairobi slaughterhouse in Kenya. Journal of Veterinary Science, 2(2):97-101.

Nchima G, Choongo K, Muzandu K, Nalubamba K, Muma J, Bumbangi F, Mongal G, Kangwa H. 2017. Determination of oxytetracycline and sulphamethazine residues in marketed beef from selected parts of Zambia to assess compliance with maximum residual limits. American Journal of Research Communication,5(9):42-69.

Nisha AR. 2008. Antibiotic residues-a global health hazard. Veterinary World, 1(12):375-377.

Olatoye IO, Ehinmowo AA. 2010. Oxytetracycline residues in edible tissues of cattle slaughtered in Akure, Nigeria. Nigerian Veterinary Journal, 31(2):93-102.

Oruç HH, Cengiz M, Bağdaş D, Uzunoğlu İ. 2007. Sığır etlerinde streptomisin ve sulfametazin (sulfadimidin) kalıntılar1. Uludağ University Journal of the Facult of Veterinary Medicine, 26 (1-2):17-20.

Ramatla T, Ngoma L, Adetunji M, Mwanza M. 2017. Evaluation of antibiotic residues in raw meat using different analytical methods. Antibiotics, 6(4):34.

Shea KM. 2003. Antibiotic resistance: what is the impact of agricultural uses of antibiotics children's health? Pediatrics, 112(1-2):253-258.

Tadesse T, Tadesse T. 2017. Public health impacts of antibiotic residues in foods of animal origin: A review. Public Policy and Administration Research, 7(10):6-11.

Tayar M, Yarsan E. 2014. Veteriner Halk Sağlığı. 1. Baskı. Dora Yayın, Bursa.

Tayar M, Yıldırım Y. 2020. Et Endüstrisi. 1. Bask1. Dora Yayın, Bursa.

Tesfaye S. 2019. A review on the antimicrobial residues and their health impacts in Ethiopia. International Journal of Microbiological Research, 10(3):139-147.

Türk Gıda Kodeksi (TGK). 2017. Hayvansal gıdalarda bulunabilecek farmakolojik aktif maddelerin sınıflandırılması ve maksimum kalıntı limitleri yönetmeliği. Resmi Gazete, 7 Mart 2017, Sayı: 30000, Başbakanlık Basımevi, Ankara.

Türkiye Bilimler Akademisi (TÜBA). 2017. İnsan ve hayvan sağlığında akılcı antibiyotik kullanımı ve antibiyotik dirençlilik raporu. Ed. Prof. Dr. Kazım Şahin. Türkiye Bilimler Akademisi Yayınları, Tüba Raporları, No:21, Ankara.

Vougat Ngom RRB, Garabed RB, Rumbeiha WK, Foyet HS, Schrunk DE, Shao D, Pagnah AZ. 2017. Penicillin-G and oxytetracycline residues in beef sold for human consumption in Maroua, Cameroon. International Journal of Food Contamination, 4:17.

Vragovic N, Bazulic D, Nijari B. 2011. Risk assessment of streptomycin and tetracycline residues in meat and milk on Croatian market. Food Chemical Toxicol, 49:352-355.

Yüksek N. 2001. Etlerde antibiyotik kalıntılarının aranması üzerinde çalışmalar. Doktora tezi. Uludağ University Journal of the Faculty of Veterinary Medicine, 20:85-90. 